\title{
Self-Adaptive Predictive Functional Control of Temperature in an Exothermic Batch Reactor
}

\begin{abstract}
In this paper we study a self-adaptive predictive functional control algorithm as an approach to control of temperature in an exothermic batch reactor. The batch reactor is situated in a pharmaceutical company in Slovenia and is used in the production of medicines. Due to mixed discrete and continuous inputs the reactor is considered as a hybrid system. The model of the reactor used for the simulation experiment is explained in the paper. Next, we assumed an exothermic chemical reaction that is carried out in the reactor core. The dynamics of the chemical reaction that comply with the Arrhenius relation have been well documented in the literature and are also summarized in the paper. Furthermore, the online recursive least-squares identification of the process parameters and the self-adaptive predictive functional control algorithm are thoroughly explained. We tested the proposed approach on the batch reactor simulation example that included the exothermic chemical reaction kinetic model. The results suggest that such implementation meets the control demands, despite the strongly exothermic nature of the chemical reaction. The reference is suitably tracked, which results in a shorter overall batchtime. In addition, there is no overshoot of the controlled variable (temperature in the reactor core), which yields a higher-quality production. Finally, by introducing a suitable discrete switching logic in order to deal with the hybrid nature of the batch reactor, we were able to reduce switching of the on/off valves to minimum and therefore relieve the wear-out of the actuators as well as reduce the energy consumption needed for control.
\end{abstract}

Key words: Self-adaptive control, Predictive functional control, Batch reactor, Exothermic chemical reaction, Hybrid systems

\section{INTRODUCTION}

Batch reactors that are cooled and heated through a water jacket are common in chemical, pharmaceutical, biotechnological and similar industries. Therefore, many papers discussing temperature control of such systems have been published.

Batch reactors and similar industrial processes contain both continuous and discrete components, for instance, discrete valves, on/off switches, logical overrides, etc. The continuous dynamics are often inseparably interlaced with the discrete dynamics; therefore, a special approach to modelling and control is required. Such dynamic systems are called hybrid systems. At first, hybrid systems were not treated systematically [1]. In recent years, however, the topic has received a great deal of attention from the computer science and control community. Batch reactors, such as the one we are dealing with in this paper, can also be regarded as hybrid systems due to the mixed discrete and continuous inputs.
Many times in industrial practice the dynamics of the batch reactor are not known in advance. Furthermore, often an exothermic (or endothermic) chemical reaction is carried out in a batch reactor, which can result in a thermal runaway. Such event can cause a loss of the batch and even presents a risk for the plant and operators. For most reaction systems of industrial interest detailed kinetic models are not known [2]. In rapidly changing chemical business, there is often not enough time or financial benefit in carrying out detailed kinetic studies of the reactions.

What is more, sometimes the same reactor has to be able to deal with different batches and thus different reaction dynamics. This calls for special control strategies. The most promising seem to be the concepts of adaptive control [3], optimal control $[4,5,6]$, and especially model predictive control schemes $[7,8,9]$. The principle of model predictive control is based on forecasting the future behavior of a system at each sampling instant using the process model. 
One of the most frequently used approaches in practice is predictive functional control [10], which is also treated in this paper. The main advantage of the approach is the analytical explicit expression of the control law, which does not require high computational capabilities and can therefore be implemented in real-time using low-cost hardware on most systems.

The paper is organized as follows. In Section 2, the batch reactor and its mathematical model are presented. Section 3 summarizes the exothermic chemical reaction dynamics. Next, the recursive least-squares identification is explained in Section 4. In Section 5, the predictive functional control algorithm is presented. Finally, the simulation results and conclusions are discussed in Section 6 and Section 7.

\section{BATCH REACTOR}

The batch reactor in the experiment is a simulation example of a real batch reactor, which is situated in a pharmaceutical company and is used in the production of medicines [11]. The goal is to control the temperature of the ingredients stirred in the reactor core so that they synthesize into the final product. In order to achieve this, the temperature has to follow the reference trajectory prescribed in the recipe as accurately as possible.

A scheme of the batch reactor is shown in Fig. 1. The reactor's core (temperature $T$ ) is heated or cooled through the reactor's water jacket (temperature $T_{j}$ ). The heating medium in the water jacket is a mixture of fresh input water, which enters the reactor through on/off valves, and reflux water. The water is pumped into the water jacket with a constant flow $\Phi$. The dynamics of the system depend on the physical properties of the batch reactor, namely, the mass $m$ and the specfic heat capacity $c$ of the ingredients in the reactor's core and in the reactor's water jacket (here, index $j$ denotes the water jacket). $\lambda$ is the thermal conductivity, $S$ is the contact area and $T_{0}$ is the temperature of the surroundings.

The temperature of the fresh input water $T_{\text {in }}$ depends on two inputs: the position of the on/off valves $k_{H}$ and $k_{C}$. However, there are two possible operating modes of the on/off valves. In case $k_{C}=1$ and $k_{H}=0$, the input water is $\operatorname{cool}\left(T_{i n}=T_{C}=12^{\circ} \mathrm{C}\right)$, whereas if $k_{C}=0$ and $k_{H}=1$, the input water is hot $\left(T_{i n}=T_{H}=150{ }^{\circ} \mathrm{C}\right)$. Both on/off valves are controlled by the signal $k_{C H}$ that is defined in the following equation. Due to the mixed discrete and continuous inputs the batch reactor is regarded as a hybrid system.

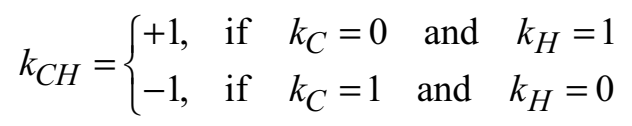

The ratio of fresh input water to reflux water is controlled by the third input, i.e. by the position of the mixing valve $k_{M}$. The value range of the mixing valve is in $[0,1]$.

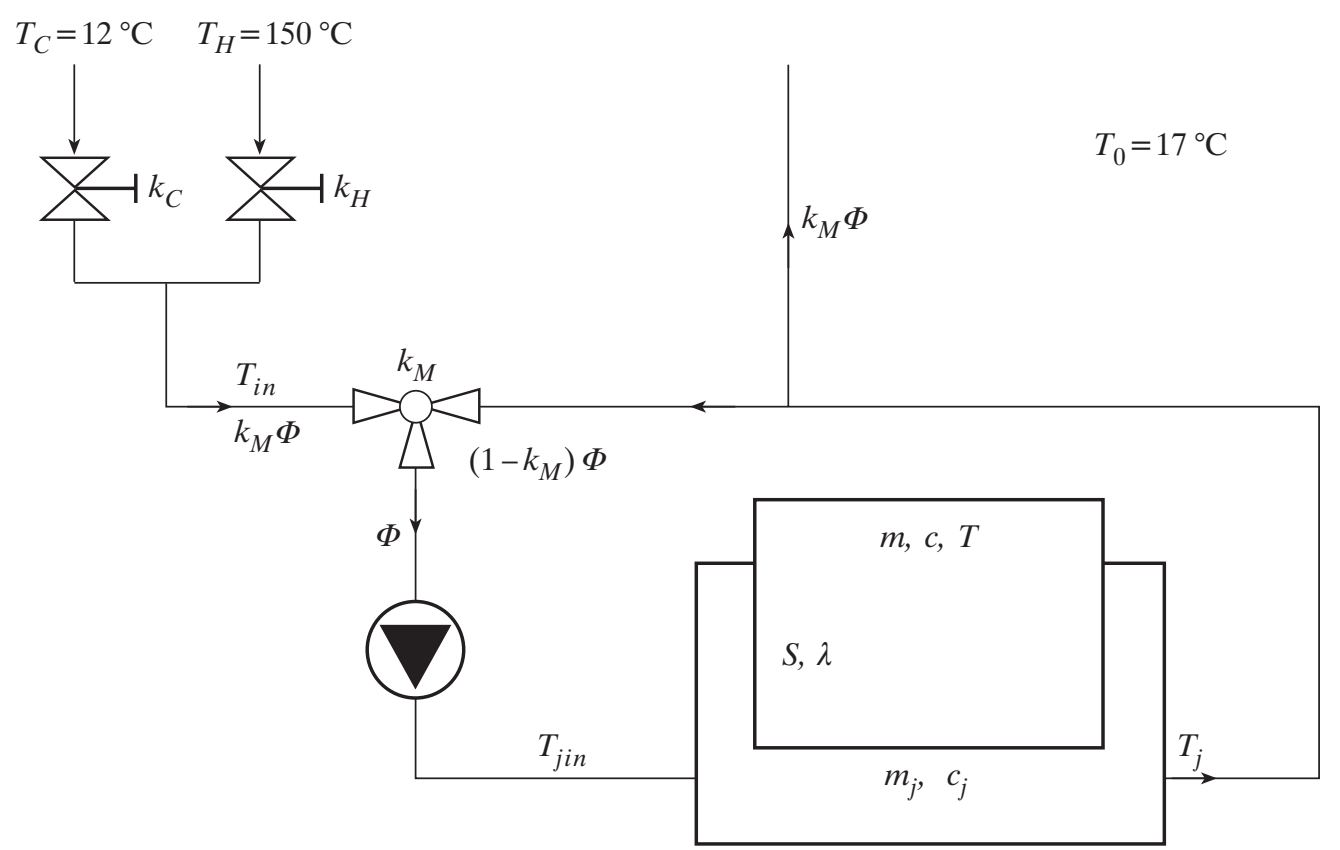

Fig. 1 Scheme of the batch reactor 


\subsection{Mathematical model of the batch reactor}

We are dealing with a hybrid multivariable system with a continuous $\left(k_{M}\right)$ and two discrete inputs $\left(k_{H}\right.$ and $\left.k_{C}\right)$ and two measurable outputs $\left(T\right.$ and $T_{j}$ ).

The temperature of the mixed water or the input jacket temperature, which is denoted as $T_{j i n}^{*}$, cannot be measured directly. However, it is possible to estimate it using the temperature of the input water $T_{i n}$, the water jacket temperature $T_{j}$, and the position of the mixing valve $k_{M}$ (see Eq. (4)). $T_{\text {jin }}^{*}$ is constrained in the range between $T_{C}$ and $T_{H}$ $\left(T_{C} \leq T_{\text {jin }}^{*} \leq T_{H}\right)$.

Due to the nature of the system, the time constant of the temperature in the water jacket is obviously much shorter than the time constant of the temperature in the reactor's core. Therefore, the batch reactor is considered as a stiff system.

The mathematical model of the batch reactor is defined by the following two differential equations and one algebraic equation.

$$
\begin{gathered}
m_{j} c_{j} \frac{\mathrm{d} T_{j}}{\mathrm{~d} t}=k_{M} \Phi c_{j} T_{i n}+\left(1-k_{M}\right) \Phi c_{j} T_{j}- \\
-\Phi c_{j} T_{j}-\lambda S\left(T_{j}-T\right)-\lambda_{0} S_{0}\left(T_{j}-T_{0}\right) \\
m_{c} \frac{\mathrm{d} T}{\mathrm{~d} t}=\lambda S\left(T_{j}-T\right)+Q_{r} \\
T_{j i n}^{*}=k_{M} T_{i n}+\left(1-k_{M}\right) T_{j}
\end{gathered}
$$

Here, $m_{j}=200 \mathrm{~kg}$ stands for the mass of the water in the jacket, $c_{j}=4200 \mathrm{Jkg}^{-1} \mathrm{~K}^{-1}$ is the heat capacity of the water in the pipes, $\Phi=1.6 \mathrm{~kg} \mathrm{~s}^{-1}$ is the mass flow in the pipes of the reactor, $\lambda=420$ $\mathrm{Wm}^{-2} \mathrm{~K}^{-1}$ stands for the thermal conductivity between the reactor core and the jacket, $\lambda_{0}=84$ $\mathrm{Wm}^{-2} \mathrm{~K}^{-1}$ is the thermal conductivity between the jacket and the surroundings. $S=2 \mathrm{~m}^{2}$ and $S_{0}=4 \mathrm{~m}^{2}$ denote the conduction surfaces between the reactor core and the jacket and between the jacket and the surrounding, respectively. The temperature of the surroundings is equal to $T_{0}=17^{\circ} \mathrm{C}$.

The aforementioned values of the parameters of the model are used only to simulate the real batch reactor in the experiment and are not used for control design. The parameters of the model used in the predictive functional control algorithm are estimated online as shown in Section 4.

The variables $m$ and $c$ stand for the mass and the heat capacity of the ingredients in the core of the reactor (see Eqs. (15) and (17) in section 3.
$Q_{r}$ in Eq. (3) denotes the heat released due to exothermic nature of the reaction among the ingredients in the core of the batch reactor (see Eq. (18) in section 3 .

\section{EXOTHERMIC CHEMICAL REACTION MODEL}

The exothermic reaction considered in this experiment is based on a dynamic model benchmark originally developed for the Warren Springs Laboratory $[12,2,13]$. A well-mixed liquid-phase reaction system is treated, in which two reactions are modelled.

$$
\begin{aligned}
& A+B \rightarrow C \\
& A+C \rightarrow D
\end{aligned}
$$

The concentration (number of moles) of components $A, B, C$ and $D$ changes according to rates of production of component $C\left(R_{1}\right)$ and $D\left(R_{2}\right)$ as given in the equations below.

$$
\begin{gathered}
\frac{\mathrm{d} M_{a}}{\mathrm{~d} t}=-R_{1}-R_{2} \\
\frac{\mathrm{d} M_{B}}{\mathrm{~d} t}=-R_{1} \\
\frac{\mathrm{d} M_{C}}{\mathrm{~d} t}=+R_{1}-R_{2} \\
\frac{\mathrm{d} M_{D}}{\mathrm{~d} t}=+R_{2}
\end{gathered}
$$

The rates of production $R_{1}$ and $R_{2}$ depend on the reactant concentrations and the rate constants $k_{1}$ and $k_{2}$.

$$
\begin{aligned}
& R_{1}=k_{1} M_{A} M_{B} \mathrm{kmol}^{-1} \mathrm{~s}^{-1} \\
& R_{2}=k_{2} M_{A} M_{C} \mathrm{kmol}^{-1} \mathrm{~s}^{-1}
\end{aligned}
$$

The rate constants $k_{1}$ and $k_{2}$ are dependent on the reaction temperature through the Arrhenius relation.

$$
\begin{aligned}
& k_{1}=\exp \frac{k_{1}^{1}-k_{1}^{2}}{T+273.15^{\circ} \mathrm{C}} \\
& k_{2}=\exp \frac{k_{2}^{1}-k_{2}^{2}}{T+273.15^{\circ} \mathrm{C}}
\end{aligned}
$$


The remaining physical variables are calculated as follows.

$$
\begin{gathered}
m=w_{A} M_{A}+w_{B} M_{B}+w_{C} M_{C}+w_{D} M_{D} \\
M=M_{A}+M_{B}+M_{C}+M_{D} \\
c=\frac{c_{A} M_{A}+c_{B} M_{B}+c_{C} M_{C}+c_{D} M_{D}}{M} \\
Q_{r}=-\Delta H_{1} R_{1}-\Delta H_{2} R_{2}
\end{gathered}
$$

The parameters of the reaction are given below:

molar weight of the components

$w_{A}=30 \mathrm{~kg} \mathrm{kmol}^{-1}$

$w_{B}=100 \mathrm{~kg} \mathrm{kmol}^{-1}$

$w_{C}=130 \mathrm{~kg} \mathrm{kmol}^{-1}$

$w_{D}=160 \mathrm{~kg} \mathrm{kmol}^{-1}$;

molar heat capacity of the components

$c_{A}=75.31 \mathrm{~kJ} \mathrm{kmol}^{-1}{ }^{\circ} \mathrm{C}^{-1}$

$c_{B}=167.36 \mathrm{~kJ} \mathrm{kmol}^{-1}{ }^{\circ} \mathrm{C}^{-1}$

$c_{C}=217.57 \mathrm{~kJ} \mathrm{kmol}^{-1}{ }^{\circ} \mathrm{C}^{-1}$

$c_{D}=334.73 \mathrm{~kJ} \mathrm{kmol}^{-1}{ }^{\circ} \mathrm{C}^{-1}$;

reaction rate constants

$k_{1}^{1}=20.9057$

$k_{1}^{2}=10000{ }^{\circ} \mathrm{C}$

$k_{2}^{1}=38.9057$

$k_{2}^{2}=17000{ }^{\circ} \mathrm{C}$;

heat of reaction

$\Delta H_{1}=-41840 \mathrm{~kJ} \mathrm{kmol}^{-1}$

$\Delta H_{2}=-25105 \mathrm{~kJ} \mathrm{kmol}^{-1}$.

\section{RECURSIVE LEAST-SQUARES IDENTIFICATION}

In our example the plant parameters are not known a priori. What is more, the chemical reaction causes the time-varying characteristics of the process. This is the reason why the parameters of the plant are estimated online. In our case we used the standard recursive estimator with exponential forgetting. To obtain the model in incremental form, the offset has to be eliminated, which is realized by fitration and differentiation of the measured signals.

The filtration and differentiation of the measured variables is realized by the filter transfer function defined as

$$
G_{f}(z)=\frac{\Delta(z)}{F(z)}
$$

where $F(z)=\left(1-f_{z}^{-1}\right)^{p}$, the parameter $f$ is defined experimentally (in our example $f=0.95, p=3$ ), $\Delta(z)=1-z^{-1}$ is the differential operator and the sampling time equals $T_{s}=20 \mathrm{~s}$. The behavior of the semi-batch reactor which is in continuous form presented in Eq. 2 and Eq. 3 is now transformed into the discrete-time domain as follows.

$$
\begin{aligned}
T_{j}^{f}(k)= & \theta_{11} T_{j}^{f}(k-1)+\theta_{12} T^{f}(k-1)+ \\
& +\theta_{13} T_{j i n}^{f}(k-1) \\
T^{f}(k) & =\theta_{21} T_{j}^{f}(k-1)+\theta_{22} T^{f}(k-1)
\end{aligned}
$$

Here, superscript $f$ stands for the filtered signals.

Defining the regression vector $\psi_{f 1}^{T}(k) \in \mathbb{R}^{1 \times 3}$, $\psi_{f 2}^{T}(k) \in \mathbb{R}^{1 \times 2}$, the output variables $y_{f 1}$ and $y_{f 2}$, and the vectors of identified parameters $\theta_{1}^{T}$ and $\theta_{2}^{T}$ as follows;

$$
\begin{gathered}
\psi_{f 1}^{T}(k)=\left[T_{j}^{f}(k-1) T^{f}(k-1) T_{j i n}^{* f}(k-1)\right] \\
\psi_{f 2}^{T}(k)=\left[T_{j}^{f}(k-1) T^{f}(k-1)\right] \\
y_{f 1}(k)=T_{j}^{f}(k) \\
y_{f 2}(k)=T^{f}(k) \\
\theta_{1}^{T}=\left[\begin{array}{lll}
\theta_{11}(k) & \theta_{12}(k) & \theta_{13}(k)
\end{array}\right] \\
\theta_{2}^{T}=\left[\begin{array}{lll}
\theta_{21}(k) & \theta_{22}(k)
\end{array}\right]
\end{gathered}
$$

the following incremental model of the semi-batch reactor in is obtained.

$$
\begin{gathered}
y_{f 1}(k)=\psi_{f 1}^{T}(k) \theta_{1}(k) \\
y_{f 2}(k)=\psi_{f 2}^{T}(k) \theta_{2}(k)
\end{gathered}
$$

The parameters of the model are estimated using the recursive least-square identification algorithm. 


$$
\begin{aligned}
& \sigma_{i}(k)=P_{i}(k-1) \psi_{f i}(k) \cdot \\
& \cdot\left(\gamma_{i}+\psi_{f i}^{T}(k) P_{i}(k-1) \psi_{f i}(k)\right)^{-1} \\
& P_{i}(k-1)=\left(I_{i}-\sigma_{i}(k) \psi_{f i}^{T}(k)\right) \frac{P_{i}(k-1)}{\gamma_{i}} \\
& \theta_{i}(k)=\theta_{i}(k-1)+\sigma_{i}(k) \cdot \\
& \cdot\left(y_{f i}(k)-\psi_{f i}^{T}(k) \theta_{i}(k-1)\right), i=1,2
\end{aligned}
$$

Here, $P_{i}(k), i=1,2$ denotes the covariance matrix $\left(P_{1}(k) \in \mathbb{R}^{3 \times 3}, P_{2}(k) \in \mathbb{R}^{2 \times 2}\right), \theta_{i}(k), i=1,2$ denotes the vector of identified or estimated process parameter, $\gamma_{i}, i=1,2$ denotes the forgetting factor and $I_{1} \in \mathbb{R}^{3 \times 3}$ and $I_{2} \in \mathbb{R}^{2 \times 2}$ are unity matrices. This means that two recursive identification algorithms are running in parallel to estimate the process parameters $\theta_{1}(k)$ and $\theta_{2}(k)$.

The dynamical behavior of the plant variables $T_{j}^{f}(k)$ and $T^{f}(k)$ according to the input jacket temperature $T_{j i n}^{f}(k)$ is given by the transfer functions $G_{m j}(z)$ and $G_{m}(z)$, which are obtained by transforming Eq. 28 into Z-domain and explicitly expressing the given relations, which are then described as follows.

$$
\begin{gathered}
G_{m j}(z)=\frac{T_{j}^{f}(z)}{T_{j i n}^{* f}(z)}=\frac{b_{1 j} z-b_{0 j}}{z^{2}-a_{1} z-a_{0}} \\
G_{m}(z)=\frac{T^{f}(z)}{T_{j i n}^{*}(z)}=\frac{b_{0}}{z^{2}-a_{1} z-a_{0}}
\end{gathered}
$$

Here, $b_{0 j}=\theta_{22} \theta_{13}, b_{1 j}=\theta_{13}, b_{0}=\theta_{21} \theta_{13}, a_{1}=\theta_{22}+$ $+\theta_{11}, a_{0}=\theta_{12} \theta_{21}-\theta_{11} \theta_{22}$ and $\theta_{23}=0$. The parameter $\theta_{23}$ equals zero $\left(\theta_{23}=0\right)$ because there is no relation between variables $T^{f}(k)$ and $T_{j i n}^{*}(k)$.

Assuming the observability of the process plant, both transfer functions, $G_{m j}(z)$ and $G_{m}(z)$, can be transformed to the observable canonical form.

Using the recursive least-squares algorithm we are always faced with the problem of the singularity of the covariance matrix $P_{i}(k), i=1,2$. The covariance matrix is exponentially increasing in the case of $\gamma_{i}<1, i=1,2$. The problem is solved by calculating the recursive algorithm only in the case of a satisfied dead-zone criterion in Eq. (35). $\psi_{f i}^{T}(k) P_{i}(k-1) \psi_{f i}(k)>k_{D Z}\left(1-\gamma_{i}\right), \quad i=1,2$

Here, $k_{D Z}$ denotes the factor of the dead-zone, which is defined heuristically.

\section{PREDICTIVE FUNCTIONAL CONTROL ALGORITHM}

In this section the well-known basic algorithm of predictive functional control is introduced [10], [14]. In this instance, the prediction of the plant output is given by its model in the state-space domain.

The behavior of the closed-loop system is defined by a reference trajectory, which is given in the form of a reference model. The control goal, in general, is to determine the future control action so that the predicted output trajectory coincides with the reference trajectory. The coincidence point is called a coincidence horizon and it is denoted by $H$. The prediction is calculated assuming of constant future manipulated variables $(u(k)=u(k+1)=$ $\ldots=u(k+H-1))$. This strategy is known as mean-level control. The H-step-ahead prediction of the plant output is estimated in Eq. (36).

$$
\begin{gathered}
y_{m}(k+H)=C_{m}\left(A_{m}^{H} x_{m}(k)+\left(A_{m}^{H}-I\right) .\right. \\
\left.\cdot\left(A_{m}-I\right)^{-1} B_{m} u(k)\right)
\end{gathered}
$$

Here, $I \in \mathbb{R}^{2 \times 2}$ is unity matrix.

The reference model is given by the following difference equation.

$$
x_{r}(k+1)=a_{r} x_{r}(k)+b_{r} w(k) y_{r}(k)=c_{r} x_{r}(k)
$$

Here, $w$ stands for the reference signal. The reference model parameters should be chosen to fulfil the following equation

$$
c_{r}\left(1-a_{r}\right)^{-1} b_{r}=1
$$

which results in a unity gain and where $c_{r}=1$ and $b_{r}$ has to be equal to $1-a_{r}$. This enables reference trajectory tracking without the control error (the asymptotic reference tracking).

The prediction of the reference trajectory is then written in the following form

$$
y_{r}(k+H)=a_{r}^{H} y_{r}(k)+\left(1-a_{r}^{H}\right) w(k)
$$


where a constant and bounded reference signal $(w(k+i)=w(k), i=1, \ldots, H)$ is assumed. The main goal of the proposed algorithm is to find a control law that enables the controlled signal $y_{p}(k)$ to track the reference trajectory.

To develop the control law, (39) is first rewritten as

$$
w(k+H)-y_{r}(k+H)=a_{r}^{H}\left(w(k)-y_{r}(k)\right)
$$

Taking into account the main idea of the proposed control law, the reference trajectory tracking $\left(y_{r}(k+i)=y_{p}(k+i), i=0,1, \ldots, H\right)$, is given by

$$
y_{p}(k+H)=w(k+H)-a_{r}^{H}\left(w(k)-y_{p}(k)\right)
$$

The idea of PFC is introduced by the equivalence of the objective increment vector $\Delta_{p}$ and the model output increment vector $\Delta_{m}$, i.e.,

$$
\Delta_{p}=\Delta_{m}
$$

The former is defined as the difference between the predicted reference signal vector $y_{r}(k+H)$ and the actual output vector of the plant $y_{p}(k)$.

$$
\Delta_{p}=y_{r}(k+H)-y_{p}(k)
$$

Substituting Equation (41) into (44) yields

$$
\begin{aligned}
\Delta_{p} & =y_{r}(k+H)-y_{p}(k)= \\
& =w(k+H)-a_{r}^{H}\left(w(k)-y_{p}(k)\right)-y_{p}(k)
\end{aligned}
$$

The model output increment vector $\Delta_{m}$ is defined by the following formula.

$$
\Delta_{m}=y_{m}(k+H)-y_{m}(k)
$$

By substituting Equations (44) and (45) into (42) and making use of Equations (41) and (36) the following control law can be obtained:

$$
\begin{aligned}
u(k) & =\eta^{-1}\left[\left(1-a_{r}^{H}\right) w(k)-y_{p}(k)\right]+ \\
& +y_{m}(k)-C_{m} A_{m}^{H} x_{m}(k)
\end{aligned}
$$

where

$$
\eta=C_{m}\left(A_{m}^{H}-I\right)\left(A_{m}-I\right)^{-1} B_{m}
$$

Note that the control law (46) is realizable if $\eta \neq 0$. This condition is true if the plant is stable, controllable and observable. This means that the PFC control law in its common form can be implemented only for open-loop stable systems. It can also be proven that the control law is integrative and the stability conditions can also be given [14]. The sensitivity to the parameter uncertainties is by introducing the integrative action into the control law reduced and also the asymptotic tracking of the reference variable is achieved. In [14] it is shown that a stable control law can always be obtained for open-loop stable systems, when the coincidence horizon $H$ is greater or equals to the relative order of the controlled system $\rho(H \geq \rho)$ as proposed.

The control algorithm in the case of the batch reactor should provide a fast reference $T_{r e f}(k)$ tracking of the temperature in the reactor's core $T(k)$. It is also very important that the number of on/off valve switchings should be as small as possible.

The position of the on/off valves $\left(k_{C H}(k)\right)$ is defined on supervisory level by introducing the decision logic which is as follows.

$$
\begin{aligned}
& \text { if } \quad T_{r e f}(k)-T(k)<\delta_{e} \text { then } \quad k_{C H}(k)=-1 \\
& \text { else } k_{C H}(k)=1
\end{aligned}
$$

Here, $\delta_{e}$ defines the switching threshold $\left(\delta_{e}=-1\right.$ $\left.{ }^{\circ} \mathrm{C}\right)$. This approach is a rather straightforward way of dealing with the hybrid nature of the batch reactor.

The position of mixing valve $k_{M}(k)$, which acts as the direct control variable, is calculated in the next step from Eq. (4).

$$
k_{M}(k)=\frac{T_{j i n}^{*}(k)-T_{j}(k)}{T_{i n}(k)-T_{j}(k)}
$$

Here, $T_{i n}(k)$ is defined with the position of the on/off valves, whereas $T_{j i n}^{*}(k)$ is obtained from the control law in Eq. (46), where it is denoted by $u(k)$.

\section{RESULTS}

The control algorithm has been verified on the batch reactor simulation example. Simulation work in [12] concerning the reaction described in section 3 suggests that an equimolar initial charge of the ingredients A and B yields the best results. In addition, the optimal reaction temperature is $95{ }^{\circ} \mathrm{C}$.

Therefore, we have established the reference trajectory $T_{r e f}$ as a step function that drops from 95 
${ }^{\circ} \mathrm{C}$ to $25{ }^{\circ} \mathrm{C}$ so as to cool the ingredients down after the reaction has settled.

The initial charge of the ingredients $\mathrm{A}$ and $\mathrm{B}$ was $M_{A}=M_{B}=2 \mathrm{kmol}$. The initial temperature was $T=T_{j}=T_{0}=17{ }^{\circ} \mathrm{C}$.

In the simulation the following initialization of the identification algorithm parameters was made: the signals were sampled with the sampling time $T_{s}=20 \mathrm{~s}$, the initial covariance matrices are equal to $P_{1}(0)=100 I_{3}$ and $P_{2}(0)=100 I_{2}$. The vectors of estimated process parameters were initialized as $\theta_{11}=\theta_{22}=1$ and the other parameters were equal to zero. The forgetting factors of the identification algorithms were set to $\gamma_{1}=\gamma_{2}=0.995$, and the factor of the dead-zone was set to $k_{D Z}=0.01$. The initialization of the generalized predictive control algorithm was the following: $H=10$ and $a_{r}=0.925$. Noise at the batch reactor outputs has also been presumed in the simulation.

Fig. 2 shows the control signals, i.e. the reference trajectory $T_{r e f}$, the temperature in the reactor core $T$ and the temperature in the reactor water jacket $T_{j}$.
Fig. 3 depicts the chemical reaction dynamics, i.e. the concentrations of the ingredients $M_{A}, M_{B}$, $M_{C}, M_{D}$ and the heat generation trajectory.

Fig. 4 and Fig. 5 show the identified process parameters $\theta$.

\section{CONCLUSION}

In this study we justified the usability of the self-adaptive predictive functional control algorithm. We tested the algorithm on a batch reactor simulation example that included a well-known exothermic chemical reaction kinetic model.

The results suggest that such implementation meets the control demands, despite the strongly exothermic nature of the chemical reaction. The reference is suitably tracked, which results in a shorter overall batch-time. In addition, there is no overshoot of the controlled variable $T$, which yields a higher-quality production.

Finally, by introducing a suitable discrete switching logic in order to deal with the hybrid nature of the batch reactor, we were able to reduce switch-
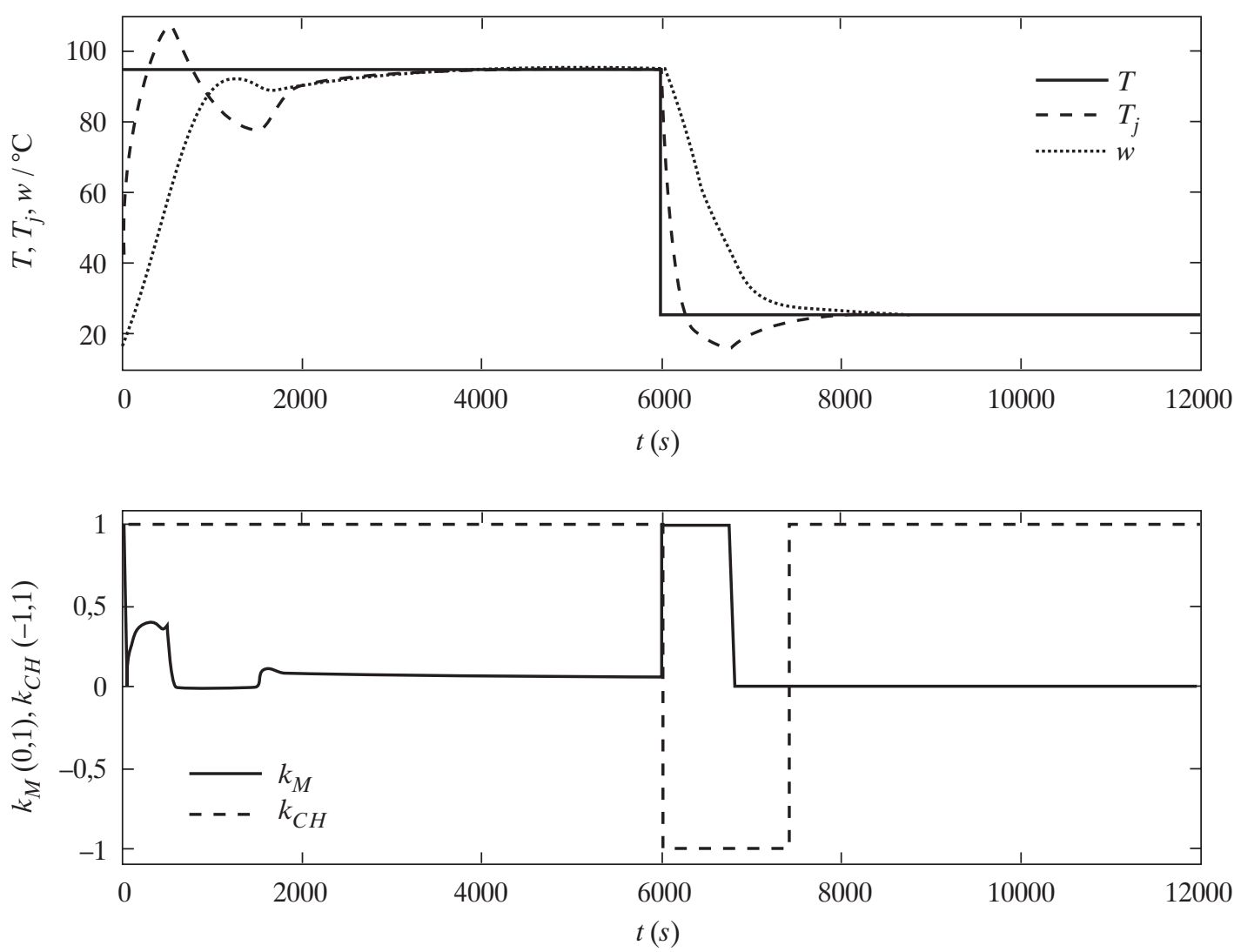

Fig. 2 Temperature trajectories and valve input signals 

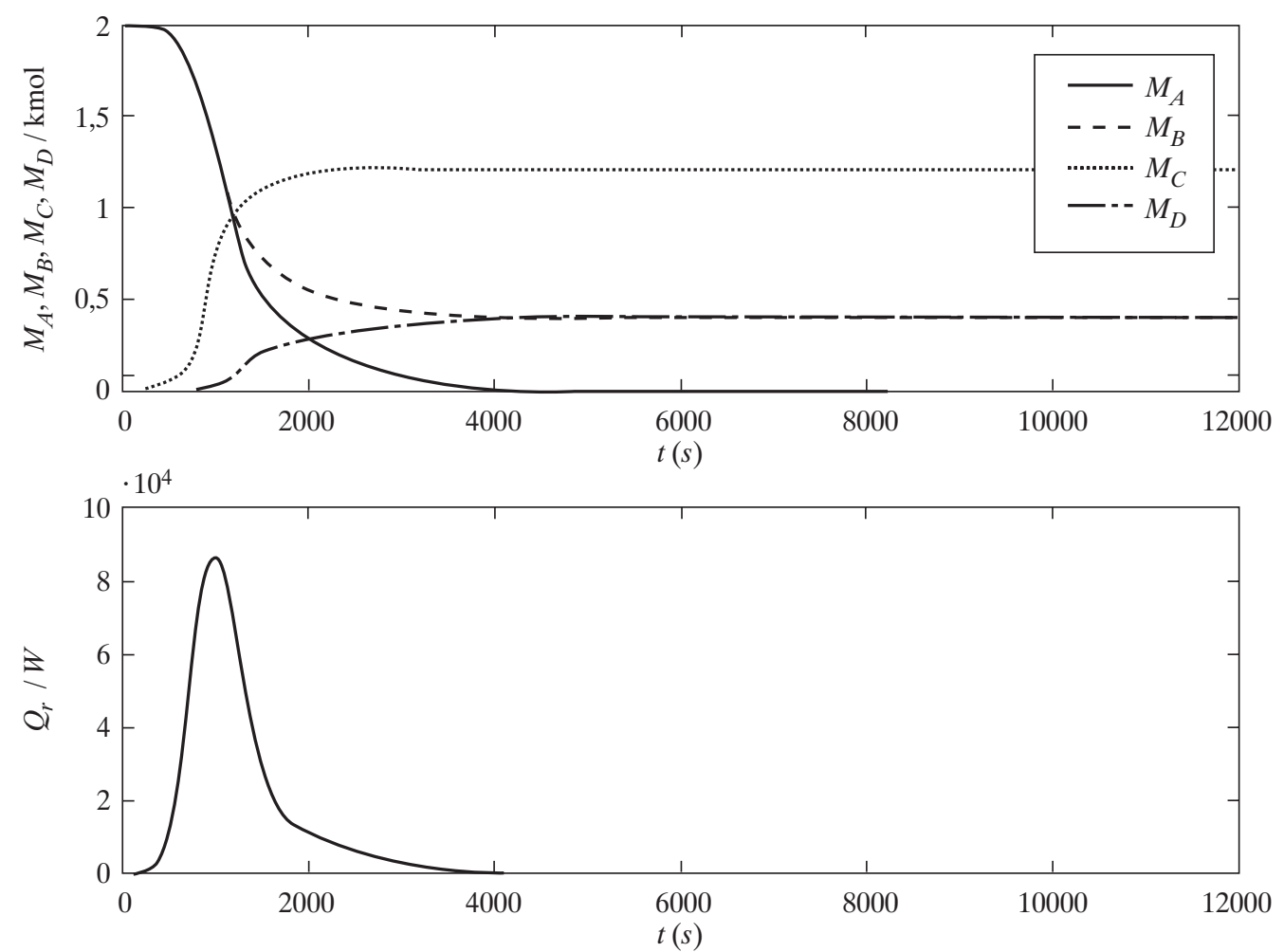

Fig. 3 Concentration trajectories and heat generation
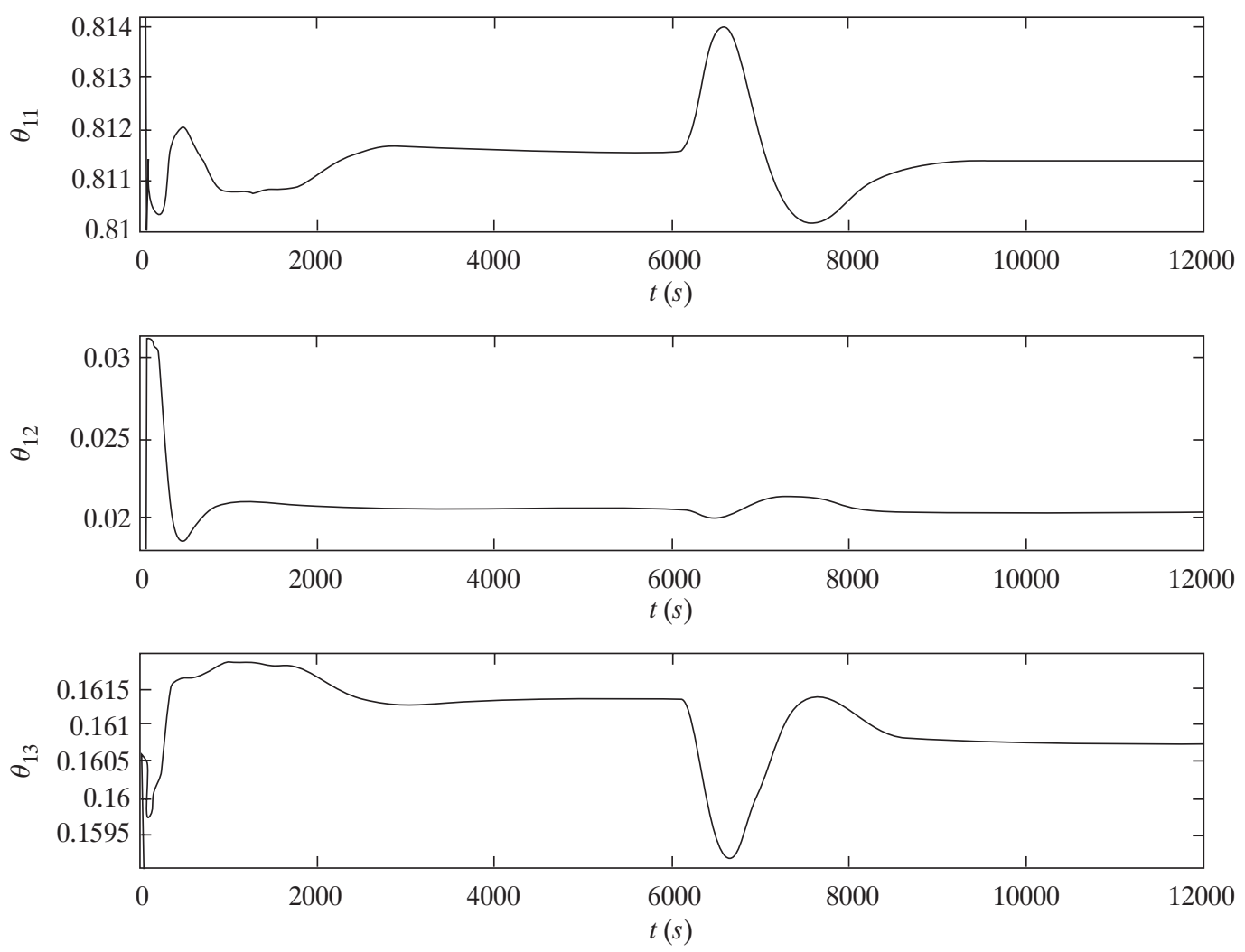

Fig. 4 The identified parameters 

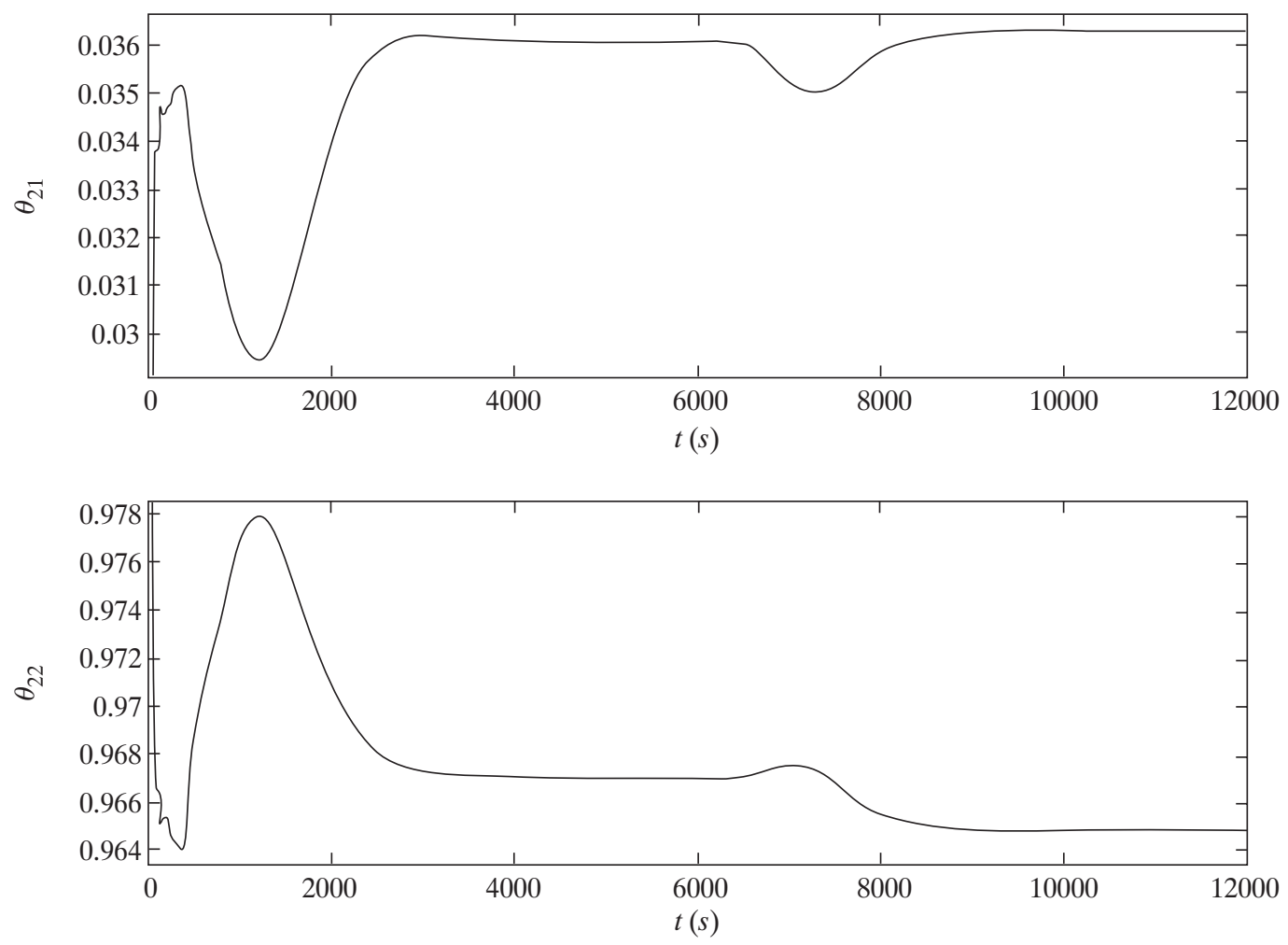

Fig. 5 The identified parameters

ing of the on/off valves to minimum and therefore relieve the wear-out of the actuators as well as reduce the energy consumption needed for control.

\section{REFERENCES}

[1] Arjan van der Schaft and Hans Schumacher, An introduction to hybrid dynamical systems. Lecture Notes in Control and Information Sciences, 251:v-vii, 1999.

[2] Barry J. Cott and Sandro Macchietto, Temperature control of exothermic batch reactors using generic model control. Industrial and Engineering Chemistry Research, 28:1177-1184, 1989.

[3] L. Chen, G. Bastin, and V. Van Breusegam, A case study of adaptive nonlinear regulation of fed-batch reactors. Automatica, 31:55-65, 1995.

[4] J. E. Cuthrell and L. T. Biegler, Simultaneous optimization and solution methods for batch reactor control. Computers and Chemical Engineering, 13: 49-69, 1998.

[5] J. S. Chang and W. Y. Hseih, Optimization and control of semibatch reactors. Industrial and Engineering Chemistry Research, 34:545-556, 1995.

[6] R. Luus and O. N. Okongwu, Towards practical optimal control of batch reactors. Chemical Engineering Journal, 75:1-9, 1997.
[7] B. A. Foss, T. A. Johansen and A. V. Sorensen, Nonlinear predictive control using local models-applied to a batch fermentation process. Control Engineering Practice, 3:389-396, 1995.

[8] N. Lakshmanan and Y. Arkun, Estimation and control of batch processes using multiple models. International Journal of Control, 72(7/8):659-675, 1999.

[9] C. Loeblin, J. D. Perkins, B. Srinivasan and D. Bonvin, Economic performance analysis in the design of on line batch optimization system. Journal of Process Control, 9:61-78, 1999.

[10] J. Richalet, Industrial application of model based predictive control. Automatica, 29(5):1251-1274, 1993.

[11] Gorazd Karer, Gašper Mušič, Igor Škrjanc and Borut Zupančič, Hybrid fuzzy model-based predicitive control of temperature in a batch reactor. Computers and Chemical Engineering, 31, 2007.

[12] R. A. Pulley, Batch process modelling. Club Report CR 2828 (CON), Warren Springs Laboratory, Herts, UK, 1986.

[13] Wonhui Cho, Thomas F. Edgar and Jietae Lee, Iterative learning dual-mode control of exothermic batch reactors. In $20055^{\text {th }}$ Asian Control Conference, pages 1270-1275, 2005.

[14] Igor Skrjanc and Drago Matko, Fuzzy predictive functional control in the state space domain. Journal of Intelligent and Robotic Systems, 31:283-297, 2001. 
Samopodešavajuće prediktivno funkcionalno upravljanje temperaturom egzotermičkog šaržnog reaktora. U članku se analizira samopodešavajući algoritam prediktivnog funkcionalnog upravljanja kao pristup upravljanju temperaturom egzotermičkog šaržnog reaktora. Šaržni se reaktor nalazi u jednoj slovenskoj farmaceutskoj tvrtki gdje se koristi za proizvodnju medikamenata. Budući da su ulazi u rektor i kontinuirani i diskretni, reaktor je promatran kao hibridni sustav. U članku je opisan model reaktora korišten za simulacije. Nadalje, pretpostavljeno je da se u jezgri reaktora odvija egzotermička reakcija. Opis dinamike kemijske reakcije Arrheniusovim jednadžbama dobro je dokumentiran u literaturi, pa je u članku dan samo kratki pregled. Posebno detaljno opisana je metoda najmanjih kvadrata za procjenu parametara modela te samopodešavajući agoritam prediktivnog funkcionalnog upravljanja. Predloženi pristup upravljanju provjeren je simulacijom na šaržnom reaktoru koji uključuje kinetički model egzoterničke kemijske reakcije. Simulacijski rezultati ukazuju da predloženo upravljanje ispunjava tražene zahtjeve, unatoč jakoj egzotermičkoj naravi kemijske reakcije. Zadane su reference dobro praćene, što rezultira skraćenjem trajanja šaržnog procesa. Osim toga, nepostojanje nadvišenja u temperaturi jezgre reaktora osigurava veću kakvoću proizvodnje. Na koncu, uvođenjem prikladne logike prekapčanja za prilagodbu hibridnoj naravi šaržnog reaktora moguće je značajno smanjiti prekapčanje dvopoložajnih ventila što ima za posljedicu smanjenje njihova trošenja i uštedu u potrošnji energije.

Ključne riječi: samopodešavajuće upravljanje, prediktivno funkcionalno upravljanje, šaržni reaktor, egzotermička kemijska reakcija, hibridni sustavi

\author{
AUTHORS' ADDRESSES: \\ Gorazd Karer, Gašper Mušič, Igor Škrjanc, \\ Borut Zupančić \\ University of Ljubljana, Faculty of Electrical Engineering \\ 1000 Ljubljana, Tržaška 25, Slovenia
}

Received: 2008-06-16

Accepted: 2008-12-23 